\title{
MEMBANGUN JATI DIRI BANGSA Globalisasi sebagai Tantangan dan Pancasila sebagai Imperatif Solusi
}

\author{
Moh. Mahfud MD \\ Fakultas Hukum \\ Universitas Islam Indonesia, Yogyakarta \\ mohmahfudmd@yahoo.co.id
}

\begin{abstract}
This article commences with a question about the existence of the real characteristics of the nation. The article then explains the nature and culture of Indonesian people as well as the negation of the characteristics of the nation. It also affirms Trisakti and geopolitics as the mosaic of the characteristics, and Pancasila as fundamental to the geopolitics. Furthermore, the article elucidates the present global challenge, mentioning a number of real cases in Indonesia. The writer assesses that the cases are the actual threats towards the sovereignty of the nation. He concludes the article by pointing out three basic measures he is assured of to take the challenge.
\end{abstract}

Key words: characteristics of the nation, Trisakti, Pancasila, Indonesia people, sovereignty of the nation

\section{Pendahuluan: Mempertanyakan Eksistensi Jati Diri}

Pada saat ini banyak keluhan bahwa kita ini sudah kehilangan jatidiri seperti yang terlihat dari perilaku kita dalam berbagai bidang: politik, sosial, ekonomi, budaya, bahkan juga ideologi. Kita sering mendengar pertanyaan yang mendalam: apakah Pancasila masih menjadi jatidiri kita sebagai bangsa? Sekelompok warga masyarakat yang sangat perduli akan kelangsungan bangsa dan negara, misalnya, juga tergugah untuk mencari jawab atas masalah itu dengan mendirikan Yayasan Jatidiri Bangsa (YJDB). Yayasan ini didirikan untuk turut berkontribusi meluruskan kembali perjalanan bangsa yang sudah agak terganggu melalui pendidikan karakter dan publikasi ide agar identitas ke-Indonesiaan atau jatidiri bangsa tetap terjaga. Pendidikan karakter, menurut YJDB penting karena karakter tidak bisa datang atau terbentuk sendiri melainkan dibentuk dan dibangun secara sadar berdasar dan menuju jati diri bangsa melalui pendidikan. Kita pun berkumpul dalam seminar hari ini karena ingin mendiagnosa gejala pelunturan jatidiri bangsa untuk kemudian mendiagnosanya serta mencari solusi penangkalnya jika gejala serangan atasnya datang sehingga jatidiri bangsa itu tetap terjaga dengan segala fungsinya. Apa fungsi jatidiri bangsa? Fungsi jatidiri adalah sebagai penanda keberadaan atau eksistensi suatu bangsa serta cerminan kondisi bangsa yang menampilkan konsep diri, identitas, perilaku, kematangan, daya juang, dan kekuatan bangsa yang menjadi pembeda dan bangsa-bangsa lain.

Dengan demikian jatidiri bangsa adalah ciri khas dan sifat-sifat khas yang menandai seseorang atau sekelompok orang atau satu bangsa yang membedakan dan masyarakat lain. Jati diri bangsa sening disamakan dengan identitas bangsa atau kepribadian bangsa.

\section{Sifat dan Budaya Manusia Indonesia}

Pernah muncul semacam polemik dan kerancuan ketika sasterawan dan wartawan Mochtar Lubis dan Wapres Republik Indonesia yang pertama Mohammad Hatta dianggap memberi penilaian negatif kepada 
sifat manusia dan budaya koruptif yang berkembang di tengah-tengah masyarakat Indonesia. ${ }^{1}$

Menurut Mochtar Lubis dalam buku Manusia Indonesia (1977) ada enam karakter manusia Indonesia, sebagai berikut.

1. Hipokrit atau munafik, misalnya berteriak-teriak akan memberantas korupsi tetapi jika ada kesempatan korupsi juga.

2. Enggan bertanggungjawab, misalnya selalu berlindung di bawah jawaban "saya hanya melaksanakan tugas" atau "saya akan terus maju karena saya belum dinyatakan bersalah oleh hukum".

3. Berjiwa feodal atau ingin agar selalu diagung-agungkan serta suka membagibagi jabatan berdasar upeti dan kedekatan (nepotis).

4. Percaya pada takhayul seperti jimatjimat dan dukun-dukun sebagai pendukung karier atau sarana untuk meraih jabatan.

5. Artistik, kreatif dalam membuat karya seni untuk kemasan, sovenir-sovenir, dan sebagainya.

6. Berwatak lemah, mudah menyerah dengan pernyataan, "Ya, sudahlah ambil hikmahnya". Bahkan kata Mochtar Lubis Bung Karno pernah mengatakan bahwa inflasi tidak apa-apa demi revolusi Indonesia" sehingga pada menjelang kejatuhannya di tahun 1965 inflasi benar-benar mencapai $650 \%$.

Dalam pada itu Bung Hatta pernah mengatakan bahwa korupsi sudah menjadi budaya bangsa Indonesia. Saya pernah mencatat juga dalam beberapa kesempatan bahwa sifat kreatif bangsa Indonesia diikuti

\footnotetext{
${ }^{1}$ Selanjutnya lihat dalam Moh. Mahfud MD, "Meneguhkan Karakter Kendonesiaan, Perspektif Karakter Manusia dan Budaya Indonesia" makalah Seminar Nasional "Merajut Kebhinekaan, Meneguhkan Karakter Ke-Indonesiaan" yang diselenggarakan dalam rangka Dies Natalis ke 63 Universitas Negeri Malang (UM) di Malang, Kamis tanggal 5 Oktober 2017.
}

juga dengan kreativitas untuk selalu memanipulasi atau menukangi kebijakan dan anggaran proyek secara koruptif jika ada masalah yang menimbulkan sikap koruptif maka kita bisa serta merta membuat peraturan untuk mengatasinya, tetapi begitu peraturan itu selesai dan diberlakukan akan ada saja akal orang Indonesia untuk mengkorupsinya atau mengimplementasikannya secara koruptif. Dalam bidang pemerintahan misalnya, kita pernah memberlakukan sistem desentralisasi yang terkendali di era Orde Baru yang oleh publik dianggap mengekang kebebasan anggota DPRD untuk bekerja demi kemajuan daerah sehingga Daerah tidak maju-maju karena sangat sentralistisbirokratis. Pada era reformasi kita mengubah hubungan antara Pusat dan Daerah menjadi Iebih demokratis dengan cara menjadikan DPRD sebagai tulang punggung otonomi daerah dan anggota DPRD (seperti juga anggota DPR) tidak dapat diberhentikan dalam masa jabatannya (recall) kecuali meninggal dunia, meminta berhenti, atau dijatuhi hukuman penjara tertentu yang sudah inkracht. Hubungan yang seperti itu dituangkan, antara lain, di dalam UU No. 22 Tahun 1999 sebagai pengganti atas UU No. 5 Tahun 1974. Tetapi kebijakan negara yang demikian malah ditukangi secara koruptif. Karena tidak bisa diberhentikan dalam masa jabatannya maka banyak anggota DPR/DPRD yang melakukan pelanggaranpelanggaran etik dan moral dengan sesuka hati dan kalau diperingatkan mereka selalu mengatakan dirinya dipilih oleh rakyat dan tidak bisa diberhentikan sembarangan. Karena DPRD dijadikan sebagai tulang punggung otonomi daerah maka dalam pengalaman banyak sekali anggota DPRD yang memeras Kepala Daerah dan menjual hak suaranya dalam pemilihan kepala daerah. Mereka bisa memeras kepala daerah dengan ancaman akan menolak laporan pertanggungjawaban tahunannya sehingga bisa dilengserkan sesuai dengan wewenang yang diberikan oleh UU kepada DPRD. 


\section{Bukan Jati Diri Bangsa}

Sifat manusia Indonesia seperti yang digambarkan oleh Mochtar Lubis dan perilaku koruptif yang, katanya, oleh Bung Hatta dianggap sebagai budaya kita pastilah bukan jatidiri bangsa karena tiga alasan. Pertama, ciri-ciri yang dikemukakan oleh Mochtar Lubis hanyalah bagian yang negatif dan keseluruhan ciri manusia Indonesia sebab masih ada ciiri-ciri Iainnya yang lebih dominan seperti beriman kepada Tuhan Yang Maha Kuasa, berperikemanusiaan, suka tolong menolong, gotong royong, ramah, santun, dan sebagainya. Kedua, budaya merupakan produk akal budi (hasil daya cipta, rasa, dan karsa) manusia yang baik sehingga tidak mungkin korupsi dianggap sebagai budaya. Selama ml kita mengklaim bahwa budaya Indonesia adalah budaya adiluhung, budaya yang hebat dan berperadaban tinggi. Maka itu korupsi tiak bisa disebut budaya melainkan harus dipandang sebagal kejahatan yang jika berkembang di dalam masyarakat harus diluruskan melalui politik kebudayaan dan politik hukum. Ketiga, kebiasaan yang buruk seperti perilaku koruptif tidak boleh dianggap sebagai budaya sebab kalau ia dianggap budaya maka berati kita tunduk dan pasrah alis bersikap fatalistik terhadap kenyataan. Padahal kebudayaan itu bersifat dinamis, bisa diarahkan atau direvitalisasi melalui politik kebudayaan. Kita bisa mencatat ketika dunia politik didominasi oleh para negarawan dan politisi yang bersih maka negara kita relatif bersih dan korupsi. Kita bisa mencatat behwa ketika perekrutan politik berhasil menjaring orang-orang yang bersih dan tegas maka korupsi bisa dimimalisir, seperti yang terjadi pada awalawal kemerdekaan sampai akhir tahun 1950-an dan pada periode-periode lain saat instusi-institusi negara dikendalikan dengan politik bersih. Bagi kita apa yang dikemukakan oleh Hatta harus dianggap sebagai peringatan dan seorang Bapak Bangsa agar kita tidak membiarkan kebiasaan ,korupsi benar-benar membudaya.

\section{Trisakti dan Geopolitik sebagai Mosaik Jati Diri Kita}

Jelaslah bahwa pencirian yang dikemukakan oleh Mochtar Lubis dan Hatta tidak bisa kita terima sebagai sesuatu yang given dan tidak bisa ditolak melainkan bisa diperbaiki melalui politik hukum dan politik kebudayaan. Seumpama pun benar bahwa yang dikemukakan oleh Mochtar Lubis dan Hatta memang ada di tengah-tengah masyarakat maka kita harus kembali ke jatidiri yang telah dikristalkan secara resmi pada saat kita menyatakan kemerdekaan atau mendirikan negara merdeka. Tepatnya secara imperatif kita harus kembali ke Pancasila. Dengan mendirikan negara merdeka maka kita sebenarnya sudah menegaskan jatidiri bangsa kita yang sama sekali tidak boleh koruptif. Seperti apa jatidiri bangsa kita? Jika dikemukakan secara sederhana tapi mengena maka azimat revolusi yang disebut Trisakti oleh Bung Karno bisa disebut sebagai simpul jatidiri kita, yakni, berdaulat secara politik, berdikari secara ekonomi, dan berkepribadian secara budaya. Azimat revolusi yang disebut Trisakti tersebut menurut saya disarikan dan geopolitik yang dikristalisasikan dan nilai-nilai Pancasila

Geopilitik bisa diartikan sebagai sistem politik atau peraturan-peraturan dalam wujud kebijaksanaan dan strategi nasional yang didorong oleh aspirasi nasional yang titik beratnya terletak pada pertimbangan geografi, wilayah atau teritorial suatu negara di bagian bumi tertentu yang ditujukan untuk mempertahankan eksistensi dan meraih tujuan-tujuan negara. ${ }^{2}$ Geopolitik bisa

\footnotetext{
${ }^{2}$ Selanjutnya lihat dalam Moh. Mahfud MD, "Sumpah Pemuda Sebagai Landasan Geopolitik dan Geostrategi" makalah yang disampaikan pada Kongres Pemuda dalam rangka Peringatan 90 Tahun Sumpah Pemuda yang diselenggarakan oleh Dewan Guru Besar Universitas Gadjah Mada di Balairung UGM Yogyakarta, Minggu tanggal 28 Oktober 2018.
} 
diartikan juga sebagai bagian bumi tempat berdirinya suatu entitas bangsa yang hidup bersama dalam satu negara yang menunjukkan posisinya di tengah-tengah bangsa dan negara-negara lain secara internasional. Jika dikaitkan secara spesifik dengan Indonesia maka geopolitik Indonesia berasal dan kristalisasi nilai-nilai budaya, sejarah yang sama dan sekelompok manusia yang hidup di irisan bumi yang sama yakni Nusantara karena nasib dan cita-cita bersama dengan membentuk satu negara milik bersama yakni Indonesia. Dalam kaitan mi geopolitik berhubungan erat dengan hubungan internasional dan perkembangan sejarah sosial untuk menjaga eksistensi Indonesia dengan segala jati dirinya. Konsep geopolitik yang seperti mi sering disebut sebagai Wawasan Nusantara. Dalam konteks hubungan internasional geopolitik merupakan upaya untuk mengatur interaksi antar kondisi internal dimana kekuatan tidak hanya dihitung dan senjata dan manusia tetapi juga harus mengenal ciri dan potensinya dengan melihat masa lalu serta sekaligus mengetahui lingkungan kita sehingga paham atas kendali-kendali negara di sekitar kita. Dalam kaitan tu pula ada dua aspek yang harus diperhatikan yakni kondisi internal dan kondisi eksternal. Secara interbal, sebagai realitas politik kita mempunyai tiga hal:

Pertama, geografi yakni hamparan bumi Indonesia yang merupakan negara kepulauan terbesar yang memiliki tiga zona waktu, memiliki 17.504 pulau yang luasnya melebihi hamparan 20 negara Eropah, memiliki empat Alur Laut Kepulauan Indonesia (ALKI) dan tujuh alur laut besar yang ada di dunia sehingga laut Indonesia menjadi alur perdagangan terbesar di dunia. Kedua, demografi yakni jumlah penduduk terbesar keempat di dunia setelah RRC (1,3 miliar), India (1 miliar), USA (326 juta), Indonesia (260 juta), dan Brasil (106 juta). Penduduk yang demikian besar dan hidup menyebar di 17.504 pulau dengan keberagaman suku (1360 suku), bahasa daerah (726 bahasa daerah), beragam agarna dan kepercayaan serta kultur. Ketiga, kekayaan sumber daya alam (SDA) yang begitu besar yang didukung oleh tanah yang subur, air yang melimpah, iklirn yang menghadirkan hujan yang seimbang dengan dua musim. Kekayaan SDA Indonesia meliputi tambang emas, tambang batu bara, cadangan gas alam, hutan hujan tropis, kekayaan laut, kesuburan tanah, hasil tanaman, dan fauna-fauna yang langka. Itulah hal-hal penting yang menggambarkan geopolitik, potret diri atau Jati diri atau identitas kita sebagai bangsa dan negara Indonesia. Intinya, geopolitik yang mencakup potret diri atau Jati diri bangsa dan negara Indonesia adalah (berangkat dan dan menuju ke) Pancasila sebagai dasar ideologi negara.

\section{Pancasila sebagal Dasar Geopolitik}

ltulah potret sekilas tentang geopolitik kita yang dikonstruksi dan Sumpah Pemuda 1928 dan diwadahi dengan rumah yang bernama Negara Kesatuan Republik Indonesia melalui proklamasi kemerdekaan pada tanggal 17 Agustus 1945. Negara Republik Indonesia dengan geopolitik di atas dilandasi oleh kesepakatan untuk menjadikan Pancasila baik sebagai dasar negara maupun selain sebagai dasar negara. Sebagai dasar negara Pancasila melahirkan aturan-aturan hukum yang tersusun secara berjenjang dalam bentuk-bentuk peraturan perundang-undangan sedangkan selain sebagai dasar negara Pancasila melahirkan norma-norma nonhukum seperti pandangan hidup bersama, pedoman pergaulan, moral, etika, dan sebagainya. Perbedaan pokok antara Pancasila sebagai dasar negara dan selain sebagai dasar negara atau Pancasila yang melahirkan hukum dan yang melahirkan pedoman nonhukum seperti norma agama (yang isinya belum dihukumkan), norma kesulilaan, dan norma kesopnan atau moral dan etika terletak pada pemberlakuan dan sanksinya 
$\begin{array}{cccc}\text { Norma } & \text { hukum yang lahir dan } \\ \text { Pancasila } & \text { sebagai dasar negara }\end{array}$ keberlakuannya ditetapkan secara resmi oleh negara melalui proses legislasi atau penetapan oleh lembaga yang berwenang sehingga mempunyai bentuk tertentu yang dituangkan dalam peraturan perundangundangan. Sedangkan norma-norma nonhukum berlaku sebagai pedoman tingkah laku di dalam masyarakat tanpa ditetapkan oleh negara atau lembaga yang berwenang, artinya berlaku karena kesadaran masingmasing orang atau komunitas pendukungnya. Penegakan atas norma hukum dilakukan secara memaksa oleh aparat negara dengan ancaman sanksiyang bersifat heteronom (datang dari kekuatan diri yang melanggar), sedangkan penegakan norma yang nonhukum tidak dapat dipaksakan oleh aparat negara dan sanksinya lebih bersifat otonom (datang dan hati yang melanggar). Di dalam kenyataan masyarakat kita banyak orang yang melanggar norma nonhukum tetapi sering merasa tidak bersalah karena tidak ada kekuatan luar yang bisa memaksanya secara heteronom. Padahal norma hukum merupakan formalisasi atau legalisasi dan norma-norma nonhukum, artinya, norma hukum tidak lain adalah norma agama, norma kesusilaan, dan norma kesopanan yang diresmikan keberlakuannya sebagai hukum oleh negara. Oleh sebab itu secara moral setiap orang seharusnya tunduk juga pada norma-norma non hukum karena norma- norma non hukum itulah yang menjadi sumber materiil norma hukum.

Pancasila sebagai dasar ideologi negara, baik yang melahirkan norma hukum maupun norma-norma non hukum, melahirkan juga empat kaidah penuntun dalam penyelenggaraan kehidupan berbangsa dan bernegara yang harus menjadi penuntun dalam geopolitik dan geostrategi Indonesia. Pertama, menjaga integrasi Indonesia baik ideologi maupun teritorinya; Kedua, membangun demokrasi dan nomokrasi; Ketiga, membangun keadilan sosial; Keempat, membangun toleransi beragama yang berkeadaban. Identifikasi geopolitik seperti yang diuraikan di atas kerapkali disamakan dengan konsep Wawasan Nusantara yang prinsip-prinsipnya meliputi:

1. Wilayah Indonesia dengan seluruh isi dan kekayaannya merupakan satu kesatuan kedaulatan dalam wadah NKRI

2. Warga bangsa yang terdiri dari berbagai ikatan primordial dan multi kultural merupakan satu kesatuan yang bulat.

3. Seluruh bangsa harus merasa satu, senasib sepenangungan, sebangsa dan setanah air serta menpunyau tekad yang sama untuk mencapai cita-cita dan tujuan bersama.

4. Pancasila merupakan satu-satunya falsafah serta ideologi yang melandasi, membimbing, dan mengarahkan bangsa untuk meraih tujuan-tujuannya.

5. Kehidupan politik di seluruh wilayah Indonesia merupakan satu kesatuan politik yang diselenggarakan berdasarkan Pancasila dan UUD 1945.

6. Perbedaan-perbedaan aspirasi antar warga negara dimungkinkan yang pengelolaannya dilakukan melalui prinsip dan mekanisme demokrasi dengan tetap menjamin integrasi.

7. Mekanisme demokrasi dilaksanakan sejalan dengan penegakan supremasi hukum (nomokrasi) agar tidak terjadi anarki.

\section{Tantangan globalisasi}

Uraian di atas memberi gambaran kepada kita tentang jatidiri kita yakni Trisakti yang bersamber dan Pancasila yang dituangkan ke dalam sistem dan peraturanperaturan yang menunjukan posisi diri secara geografisdengan nilai-nilai dan sikap yang khas sebagai bangsa dengan demografi dan kekayaan alamnya.

Masalahnya, ada kehawatiran bahwa jatidiri kita sudah mulai tergerus baik karena faktor eksternal yang merupakan konsekuensi dan globalisasi maupun karena faktor internal yang berkembang dan proses- 
proses kehidupan bernegara dalam segala bidang. Secara ekternal karena kita ini berada di tengah-tengah dunia internasional yang jika dilihat dan sudut hubungan antar negara mempunyai geopolitiknya masingmasing maka kita memang terkepung oleh situasi yang bisa mempengaruhi jatidiri kita.

Sebagai tantangan globalisasi yang semakin masif membawa empat tuntutan hati nurani global (global conciusness) yakni, perlindungan atas hak-hak asasi manusia, demokratisasi, pemeliharaan lingkungan hidup, dan ekonomi pasar bebas. Keempat hal tersebut sekarang ini selalu menjadi perhatian dunia yang tidak bisa dihindari. Pelanggaran HAM di suatu negara bisa memicu keterlibatan dunia, pemerintahan yang tidak demokratis bukan hanya diprotes oleh rakyat domestiknya melainkan juga menjadi sorotan dunia internasional, perusakan atas lingkungan hidup bisa memicu reaksi internasional, dan ekonomi pasar bebas masuk ke dalam negara kita melalui instrumen-instrumen internasional.

Kesalahan dalam menangani empat hati nurani global itu bisa merusak konsep geopolitik kita bahkan merongrong kedaulatan negara. Contohnya, sebagai warga negara Indonesia saya pernah merasa tersinggung ketika pada tanggal 4 Agustus 2015 Pemerintah Singapura mengundangkan The Transboundary Haze Pollution Act (THPA) atau, singkatnya, UU Anti Asap yang isinya, antara lain, Pemerintah Singapore boleh menangkap dan menghukum pembakar hutan di negara lain (tentunya juga terutama Indonesia) yang karena kesalahannya asap pembakaran hutan tersebut mengganggu warga Singapore. Bagi ilmu hukum pidana hal ini memang terlihat aneh dan serta merta dapat disikapi bahwa UU tersebut salah dan kita tidak terikat kepadanya. Tetapi bisa dipastikan bahwa Pemerintah Singapore bukan tidak tahu tentang kejanggalan tersebut namun mereka punya alasannya sendiri. Mereka bisa mengatakan bahwa Singapore berhak membuat UU untuk melindungi keselamatan rakyatnya sesuai dengan konvensi internasional bahwa setiap negara dapat mengambil langkah-Iangkah yang diperlukan untuk melindungi eksistensi negaranya. Singapore memang tidak bisa masuk ke Indonesia untuk menangkap pembakar hutan tetapi dengan UU tersebut pihak Singapore bisa menangkap pembakar hutan (orang maupun korporasi) di Indonesia yang datang ke Singapore (dengan mengkap sendiri) atau menggunakan interpol jika si pembakar hutan datang ke negara lain. Lebih dari itu alasan Pemerintah Singapore mengeluarkan UU Anti Asap itu adalah karena pihak Singapore menganggap Indonesia tidak bisa menegakkan hukum dan menghukum pembakar hutannya yang selalu terjadi hampir setiap tahun. Mungkin pihak Singapore bermaksud mengatakan, "jika Anda tidak bisa menegakkan hukum kepada orang-orang yang membakar hutan sedangkan asapnya selalu mengancam kehidupan rakyat kami maka kami bisa membuat hukum sendiri". Jatidiri kita sebagai negara dan bangsa yang taat hukum danmempunyai kedaulatan hukum sendiri menjadi terlecehkan kalau kita tidak mampu menegakkan hukum kita sendiri.

Ada contoh lain, dulu pernah ramai diberitakan empat polisi air Indonesia yang menjaga perbatasan laut di Riau menangkap empat orang penangkap ikan dan Malaysia yang melanggar perbatasan perairan Indonesia. Namun ketika para polisi air kita itu membawa pelanggar batas itu menuju daratan Indonesia mereka diburu oleh kapal patroli Malaysia yang lebih canggih dan akhirnya mereka dibawa dengan paksa ke Malaysia untuk selanjutnya ditahan disana. Meskipun jelas warganya melanggar batas namun pihak Malaysia tidak mau keempat warganya diadili oleh Indonesia, mereka malah menuduh polisi air Indonesia lah yang melanggar perairan Malaysia. Jalan diplomasi yang akhirnya disepakati adalah keempat polisi air Indonesia dipulangkan tetapi keempat warga Malaysia itu pun tidak perlu diadili di Indonesia. Kalau Indonesia bersikeras meminta untuk mengadili mereka 
karena melanggar perairan Indonesia maka pihak Malaysia mengancam bahwa mereka pun bisa mengadili lebih dari satu juta orang Indonesia yang menjadi pendatang haram di Malaysia. Dalam kasus ini jatidiri kita sebagai bangsa yang mempunyai kedaulatan politik atas wilayahnya menjadi ternodai larena kita tidak mampu memberi tempat yang semestinya bagi warga negara kita sendiri atau menyiapkan diri dengan baik untuk mencari hidup di dalam negeri.

Jadi gangguan terhadap kedaulatan negara kita bisa terjadi karena keadaan kita yang kurang mampu menegakkan hukum ke dalam sehingga negara lain membuat hukumnya sendiri yang melecehkan dan bertendensi melanggar kedaulatan hukum Indonesia. Adakalanya juga hal itu terjadi karena kita belum mampu memberi lapangan kerja yang layak terhadap warga negara kita sendiri sehingga mereka berbondong-bondong mencari hidup di luar negeri, ada yang berangkat dengan legal, ada yang menyelusup dengan ilegal. Dalam keadaan begitu posisi tawar kita menjadi lemah sehingga kedaulatan pun menjadi taruhan dalam berhadapan dengan negara lain. Kita bisa kehilangan kedaulatan hukum karena tidak mampu berhukum dengan baik dan kehilangan kedaulatan politik karena tidak mampu membangun ekonomi secara mandiri.

Dalam beberapa kasus pelemahan atas kedaulatan terjadi juga karena kesalahan kita dalam melakukan perekrutan politik. Perekrutan politik kita berlangsung secara kolutif dan koruptif sehingga pembuatan hukum dan kebijakan pun bisa melemahkan kedaulatan kita. Sistem politik kita sekarang ini mempunyai potensi besar untuk Iahirnya berbagai peraturan dan kebijakan yang tidak memihak rakyat. Kalau dalam situasi sekarang, misalnya, kita bisa menunjuk dengan mudah tentang banyaknya operasia tangkap tangan (OTT) oleh Komisi Pemberantasan Korupsi karena jual beli dalam pembuatan hukum atau berbagai kebijakan. Ada yang mengatakan bahwa yang tertangkap itu pun karena apes, tidak mempunyai backing kekuasaan sehingga terjebak di pojok yang mudah ditangkap sebab sesungguhnya yang tidak terkena OTT pun melakukan hal yang sama. Kita juga menengarai terjadinya korupsi dalam pembuatan peraturan perundang-undangan sehingga korupsi tidak lagi terjadi di hilir (dalam bentuk proyek) melainkan terjadi sejak di hulunya ketika UU APBN atau Perda APBD dibahas (melalui suap menyuap). Proses perekrutan politik kita membuka peluang terjadinya jual beli pembuatan hukum dan kebijakan publik ini. Jual beli hukum dan kebijakan ada kalanya bukan hanya terjadi dalam pembuatan aturan dan kebijakan di dalam negeri tetapi juga dalam hukum-hukum yang terkait dengan hubungan perdagangan internasional. Penerapan WTO Agreement 1984 melahirkan contoh tentang itu. Instrumen internasional itu memberlakukan keterbukaan lalu lintas barang dan jasa antar negara dalam rangka pasar bebas. Indonesia menerapkan dengan begitu saja asas "resiprosivitas" (pemberlakuan syarat yang sama kepada semua orang sehingga pihak luar negeri mudah masuk ke Indonesia, sedangkan negara-negara lain banyak yang menggunakan asas perlindungan "kepentingan nasional" sehingga tidak mudah dimasuki oleh pengusaha atau perusahaan Indonesia. Baik asas reprosivitas maupun asas perlindungan kepentingan nasional sama-sama merupakan asas dalam hubungan perdagangan internasional. Apa akibatnya? Perusahaan minyak Malaysia (Petronas, Shell) bisa dengan mudah membuka pom bensin di sini, sedangkan kita sangat sulit untuk membuka pom bensin (Pertamina) di Malaysia. UU Perbankan kita juga membuka pintu kepada pihak asing untuk menguasai 99\% modal Bank yang beroperasi di Indonesia dengan jaminan Sertifikan Bank Indonesia (SBI) yang dapat menutup jika Bank-bank tersebut rugi. Menurut saya lahirnya UU seperti ini tidak dapat dikatakan karena kita benar-benar patuh kepada kesepakatan-kesepakan internasional melainkan selain karena 
pembentuk hukum-hukum kita mungkinn tidak paham tetapi juga karena memang bermaksud melakukan kolusi dan korupsi. Coba lihat juga kasus Freeport yang karena UU dan kebijakan pada masa lalu menyebabkan kita sampai sekarang tidak bisa leluasa untuk menikmati tambang emas tersebut guna mensejahterakan rakyat kita sendiri.

\section{Simpulan}

Tampak jelas bahwa kita mengalami gangguan dalam menegaskan identitas atau jatidiri sebagai bangsa yang gagah, bermartabat, dan berdaulat. Azimat Trisakti mulai hilang kesaktiannya karena dalam faktanya secara politik kedaulatan kita ternoda, secara ekonomi kita tidak bisa membangun kemandirian (berdikari) yang bisa menjamin pemerataan, dan secara budaya pun kepribadian kita mulai ternodai.

Tentu banyak faktor dan banyak disiplin ilmu yang bisa mendiagnosa dan menterapi gejala-gejala pelunturan jatidiri ini. Setiap kita yang hadir disini bisa mendiagnosa dan menawarkan terapi berdasar disiplin ilmu masing-masing.Tetapi saya akan mencoba menyimpulkan dari disiplin ilmu yang saya dalami (ilmu hukum, ilmu politik, dan ilmu politik hukum) bahwa penodaan atas jatidiri harus diatasi dengan tekad menempuh langkah-langkah sebagai berikut secara simultan:

Pertama, tegakkan hukum dan keadilan tanpa pandang bulu karena runtuhnya suatu bangsa dan negara kerapkali disebabkan oleh bekerjanya proses empat dis (disoriented, distrusted, disobedience, disintegrated) ketika hukum dan keadilan tidak ditegakkan dan akibatakibatnya dibiarkan hingga berlarut-larut.

Kedua, perbaikan sistem perekrutan politik agar tidak kolutif dan koruptif seperti yang menggejala beberapa dekade terakhir ini. Dilihat dari hubungan antara hukum dan politik, dan satu segi, dapat didalilkan bahwa hukum adalah produk politik. Jika perekrutan politiknya baik maka hukumhukumnya juga akan baik.
Ketiga, kita harus menyiapkan sumberdaya manusia yang adaptif terhadap masifikasi teknologi informasi yang selalu meningkatkan kecanggihan digitalisasi. Pendidikan harus mampu menyiapkan anakanak kita (yang sekarang sudah didominasi oleh generasi $\mathrm{Y}$ atau milenial) agar mampu mengimbangi kemajuan IPTEK dengan basis IMTAQ. Dalam konteks ini negara harus mampu menjamin tegaknya hukum dan keadilan serta politik yang demokratis secara substantif. Jika hukum dan keadilan lumpuh dan politik tidak demokratis secara substantif tidak berkembang maka kesetiaan generasi penerus terhadap bangsa dan negaranya akan meluntur dan mereka bisa melakukan langkah-langkah di luar komitmen kebangsaannya untuk mengaktualisasikan jalan hidupnya.

\section{Semarang, 14-16 November 2018.}

* Disampaikan pada Seminar Nasional Interaktif Jati Diri Bangsa: Merajut dan Meneguhkan Jati Diri, Dewan Profesor Senat Akademik Universitas Diponegoro dan Majelis Dewan Guru Besar Perguruan Tinggi Bada Hukum, Semarang, 14-16 November 2018.

\section{Daftar Pustaka}

Bell, Daniel. 1960. The End of Ideology: On the exhaustion of Political Ideas in Fifties. New York: Free Press.

Edgar, Bodenheimer. 1967. Jurisprudence: The Philosophy and Method of Law. Cambridge: Harvard University Press.

Feith, Herbert. 1962. The Decline of Constitutional Democracy in Indonesia. New York: Cornell University Press.

Fukuyama, Francis. 1992. The End of History and the Last Man. London: Hamish Hamilton.

Hatta, Muhammad. 1989. Pengertian Pancasila. Jakarta: CV Haji Masagung. 
Huntington, Samuel P. 1911. The Clash of Civilization and Remaking of World Order. London: Simon \& Schuster.

Kahin, George Mc.T. 1952. Nationalism and Revolution in Indonesia. New York: Cornell University Press.

Kaelan. 2002. Filsafat Pancasila Pandangan Hidup Bangsa Indonesia. Yogyakarta: Paradigma.

Kelsen, Hans. 1973. General Theory of Law. New York: Russel \& Russel.

Lev, Daniel S. 1990. Hukum dan Politik di Indonesia. Jakarta: LP3ES.

Lubis, Mochtar. 6 April 1977. Ciri Manusia Indonesia. Pidato Kebudayaan di Taman Ismail Marzuki Jakarta.

Mahfud MD, Mohammad. 1998. Politik Hukum di Indonesia. Jakarta: LP3ES. 2012. Membangun Politik

Hukum, Menegakkan Konstitusi. Jakarta: Rajawali Press.

Otter, Roland C Den.2007. Judicial Review in an Age of Moral Pluralism. New York: Cambridge University Press.

Poespowardojo, Soejanto. 1989. Filsafat Pancasila: Sebuah Pendekatan Sosio Budaya. Jakarta: Gramedia.

Soekarno. 1963. Di Bawah Bendera

Revolusi. 2 Jilid. Jakarta: Penerbit Di Bawah Bendera Revolusi.

Steger, Manfred. 2002. Globalism: the New Market Ideology. New York: Rowman and Littlefield Publishers. 